\title{
Assessing the Role of Temperature, Inoculum Density, and Wounding on Disease Progression of the Fungal Pathogen Ceratocystis fimbriata Causing Black Rot in Sweetpotato
}

\author{
M. Stahr and L. M. Quesada-Ocampo ${ }^{\dagger}$ \\ Department of Entomology and Plant Pathology, North Carolina State University, Raleigh, NC 27695-7616
}

\begin{abstract}
In 2014, Ceratocystis fimbriata, causal agent of black rot in sweetpotato, reemerged and inflicted large financial losses on growers in the United States. Black rot continues to damage sweetpotatoes and has become a priority to the industry since then. In contrast, little is known about the biology of $C$. fimbriata and the epidemiology of sweetpotato black rot. In this study, effects of environmental factors such as inoculum density, $\mathrm{RH}$, and temperature on sweetpotato black rot were determined. Cured sweetpotatoes were wounded with a toothpick to simulate puncture wounds, inoculated with different spore suspensions (inoculum density) $\left(10^{4}, 10^{5}\right.$, or $10^{6}$ spores $\left./ \mathrm{ml}\right)$, and incubated under different RH $(85.53$, 94.09 , or $97.01 \%)$ and temperature $\left(13,18,23,29\right.$, or $\left.35^{\circ} \mathrm{C}\right)$ for 21 days. In a separate experiment, five root wounding types (cuts, punctures, abrasions, end breaks, and macerating bruises) were compared. All wounded roots were subsequently soaked in a $10^{3}$ spores $/ \mathrm{ml}$ suspension and incubated at $100 \% \mathrm{RH}$ and $23^{\circ} \mathrm{C}$ for 21 days. This study found 29 and $23^{\circ} \mathrm{C}$ to

be the optimal temperature for black rot disease development and sporulation, respectively. No pathogen growth was observed at 13 and $35^{\circ} \mathrm{C}$. Increased inoculum density significantly $(P<0.0001)$ increased disease incidence, but increasing RH had an effect only on sporulation area. All wound types resulted in increased disease incidence and sporulation as early as 7 days postinoculation. Our results highlight the importance of characterizing factors that affect disease development for achieving successful disease management strategies. Findings from this study will be used to improve disease management for sweetpotato black rot by suggesting tighter regulation of curing and storage conditions and better postharvest handling of sweetpotato roots to avoid unnecessary wounding.

Keywords: causal agent, crop type, cultural and biological practices, disease development and spread, disease management, epidemiology, fungi, vegetables
\end{abstract}

Sweetpotato (Ipomoea batatas) is one of the most important food crops around the world. The high content of vitamin A and other essential nutrients found in sweetpotato help combat nutritional disorders and famines in parts of Africa and Asia (Loebenstein 2009). In addition, sweetpotato roots and vines (Woolfe 1998) are widely used across the globe in animal feed, pet food production, and an increasing number of commodity products such as fries, chips, and juices (Bickers 2015; Scott 1992).

Because of the increased popularity of sweetpotato products, production within the United States has inflated from a \$400-million industry in 2009 to a net worth of $\$ 600$ million in 2014 (Food and Agriculture Organization of the United Nations 2014). Multiple states produce sweetpotatoes but the expansion of sweetpotato production is most notable in North Carolina (North Carolina Department of Agriculture and Consumer Services 2015), where more than half of the nationwide production is done on 80,000 acres (Johnson et al. 2015; North Carolina Department of Agriculture and Consumer Services 2015). Unfortunately, this expansion is not immune to disease issues, leading to increasing annual losses at all stages of production (Scruggs and Quesada-Ocampo 2016a, b). Without the

${ }^{\dagger}$ Corresponding author: L. M. Quesada-Ocampo; lmquesad@ncsu.edu

Funding: This work was supported by funds from the North Carolina Sweetpotato Commission, North Carolina Certified Sweetpotato Seed Growers Association, Specialty Crop Block Grant Program (award 15SCBGPNC0003), North Carolina State University Hatch Project (NC02628), and Bill and Melinda Gates Foundation.

*The $\boldsymbol{e}$-Xtra logo stands for "electronic extra" and indicates that one supplementary figure is published online.

The author(s) declare no conflict of interest.

Accepted for publication 6 September 2019.

(C) 2020 The American Phytopathological Society proper knowledge to combat these diseases, observed losses can become quite severe.

Black rot of sweetpotato, a postharvest disease caused by Ceratocystis fimbriata, was first identified in 1890 (Halsted 1890) and is historically considered one of the most important diseases of sweetpotato (Clark and Moyer 2013). In the past, this disease had been all but eliminated as a result of proper management strategies. However, in 2014, an unusual and significant increase in black rot incidence was observed in North Carolina, a trend that was repeated in multiple states the following year (Scruggs et al. 2017). This reemergence of $C$. fimbriata has caused several issues not just in North America but also overseas where sweetpotato shipments are rejected as a result of postharvest rots en route to export markets. With the increase in outbreaks, losses in yield and postharvest for sweetpotato packers and growers have been estimated to 60 to $80 \%$ loss, corresponding to $>\$ 150$ million (Quesada-Ocampo, personal communication).

Attempts to reduce disease-related losses occur throughout all stages of sweetpotato production. Current recommendations maintain that sweetpotatoes should be handled with care because roots can acquire wounds and bruises while being harvested, put into or brought out of storage, and packaged for distribution and sale (Edmunds et al. 2008). Sweetpotatoes are capable of suberization to heal wounds, which provides substantial protection from disease (Lauritzen 1935) but requires a minimum 2-day period, appropriate moisture to prevent wound desiccation, and warm temperatures (Morris and Mann 1955; Smith et al. 2009; Wiemer and Harter 1921). Growers most often achieve these conditions during the curing process, which occurs between harvest and storage and involves holding the roots at $29^{\circ} \mathrm{C}$ (or $85^{\circ} \mathrm{F}$ ) for 3 to 5 days. The curing process not only provides growers the protective benefits of suberization but also helps dry the roots, allows for the setting of sweetpotato skin, and enhances culinary characteristics (Edmunds et al. 2008; Loebenstein 2009).

Although many of these methods of pathogen avoidance have been in practice for years, very little is known about the finer details of the relationship between $C$. fimbriata and its sweetpotato host, 
particularly when in storage. The limited information that is available indicates that $C$. fimbriata can disperse and grow under storage conditions and tends to appear on wounds, lenticels, or lateral roots (Clark and Moyer 2013). This small composite of knowledge fails to address how wounding or environmental storage conditions, other than just temperature (Kushman and Cooley 1946; Lauritzen 1926), may favor disease development, as well as what role inoculum plays in the spread of disease. The lack of available information on these topics is problematic, as these considerations are all important when orchestrating effective disease management.

In other pathosystems, studies investigating diseases such as Fusarium root rot and Rhizopus soft rot have addressed how wounding and varying environments can affect disease development. Investigation of wound type using Rhizopus stolonifer found that the manner of the wound could strongly influence disease, because crushing wounds had much higher decay rates than simple abrasions and other wounds (Holmes and Stange 2002). Furthermore, studies of Fusarium and Rhizopus species, Lasiodiplodia theobromae (causal agent of java black rot), and Macrophomina phaseolina (causal agent of charcoal rot) revealed that disease development was greatest for multiple pathogen species at or within a range including $29^{\circ} \mathrm{C}$ (Lauritzen 1935; Scruggs and QuesadaOcampo 2016a, b), the temperature where roots are held for curing. These results indicate that the current curing process is not necessarily well suited for reducing disease occurrence. However, with little scientific evidence to support this notion in black rot, an appropriate curing regime capable of combating a broad spectrum of postharvest diseases cannot be determined. Alternatively, chemical control can be used in both pre- and postharvest settings to reduce disease incidence and severity. Unfortunately, fungicides currently labeled for use in sweetpotato have limited activity against the spread and development of black rot, particularly in postharvest settings, except for the group 1 fungicide thiabendazole, which is only available in North Carolina through an emergency label (Quesada-Ocampo 2014). The lack of chemical control only perpetuates the struggle against black rot and makes the need for alternative management practices more dire.

This study aimed to (i) evaluate how environmental storage conditions such as temperature, humidity, and inoculum density impact disease development and (ii) assess which wound types can increase the risk of disease incidence. By obtaining this information, accurate recommendations can be made to alter or optimize current management strategies for postharvest handling of

Table 1. Mean RH observed within the sterile containers across all tested temperature treatments over the course of each 21-day study

\begin{tabular}{lc}
\hline Theoretical RH $(\boldsymbol{\%})$ & Experimental RH $(\boldsymbol{\%})^{\mathbf{z}}$ \\
\hline 80 & $85.53 \pm 0.20$ \\
90 & $94.09 \pm 0.10$ \\
100 & $97.01 \pm 0.11$ \\
\hline
\end{tabular}

${ }^{\mathrm{z}}$ Values are presented as mean $\mathrm{RH} \pm$ standard error. sweetpotatoes to reduce such significant losses as caused by C. fimbriata.

\section{Materials and Methods}

Host and pathogen material. The sweetpotato variety Covington is the most widely grown cultivar in North Carolina. Covington roots were acquired from local packing houses after being cured and held in storage for an undetermined period of time since harvest within industry standards (Edmunds et al. 2008). Roots were surface sterilized by being soaked for $10 \mathrm{~min}$ in a $10 \%$ bleach solution $(0.6 \%$ sodium hypochlorite), rinsed with distilled water, and then dried in a laminar flow hood. C. fimbriata isolate AS186, obtained in 2014 from a North Carolina packing house (Scruggs et al. 2017), was used in all experiments. AS186 was revived from storage by transferring stored mycelial plugs, kept in a $25 \%$ glycerol solution held at $-80^{\circ} \mathrm{C}$, onto fresh carrot agar plates $(16 \%$ Bolthouse Farms carrot juice, $16 \mathrm{~g}$ of select agar per liter). Plates were kept under constant, fluorescent lights at room temperature. Once growth was observed, the cultures were transferred to fresh plates and held under ambient light and temperature conditions until needed.

Mixed spore suspensions of isolate AS186, containing ascospores and endoconidia, were collected from 10-day-old carrot agar plates and used as pathogen inoculum. While the plates were in a biosafety cabinet, $2 \mathrm{ml}$ of a 5\% Tween-20 (molecular biology grade) solution was added to each plate. As other research with $C$. fimbriata has shown, ascospore masses can be difficult to separate into solution without the use of industrial solvents (Baker et al. 2003; Baker Engelbrecht and Harrington 2005); therefore, the investigators gently dislodged ascospore masses from the perithecia by hand, while wearing sterile gloves with frequent ethanol sterilization, and massaged them against the agar plate to free ascospores from the extracellular matrices to produce both single and small, countable clusters of ascospores in suspension. The spore suspension was gathered from the plate, and the stock concentration was determined with a hemocytometer.

Effect of temperature, humidity, and inoculum density on disease development. In this experiment, five temperatures (13, $18,23,29$, and $\left.35^{\circ} \mathrm{C}\right)$, three RH levels $(80,90$, and $100 \%)$, and four inoculum densities $\left(0,5.0 \times 10^{4}, 5.0 \times 10^{5}\right.$, and $5.0 \times 10^{6}$ spores $\left./ \mathrm{ml}\right)$ with a negative control were tested for their effect on disease development. Each treatment combination of temperature, humidity, and inoculum density was assigned to six roots. Roots with the same treatment combination were placed as pairs in clear, sterile $28 \times$ $20 \times 14-\mathrm{cm}$ plastic containers with roots serving as subsamples and the containers serving as the experimental unit. Data collected from subsamples were averaged together during the statistical analysis. Overall there were three replicates (i.e., containers) per treatment combination. The entire experiment was performed twice.

From the stock spore suspension, dilutions of $5.0 \times 10^{4}, 5.0 \times 10^{5}$, and $5.0 \times 10^{6}$ spores $/ \mathrm{ml}$ in sterile distilled water (SDW) were prepared. To increase the chance of successful inoculation, roots were wounded by puncturing their flesh with a sterilized toothpick to a depth of $10 \mathrm{~mm}$ as done in prior studies (Scruggs et al. 2017). For ease of inoculation, 20- $\mu \mathrm{l}$ aliquots of either the three spore

Table 2. Description of wound types used to assess the effect of wounding on black rot disease development in sweetpotato roots ${ }^{\mathrm{z}}$

\begin{tabular}{|c|c|c|}
\hline Wound type & Tool used & Description of injury \\
\hline Control & None & $\begin{array}{l}\text { No injury made; the circular portion of the central body of the sweetpotato was marked } \\
\text { with a marker for a consistent rating area }\end{array}$ \\
\hline Puncture & Toothpick & Small 10-mm deep stab wound in the central body of the sweetpotato \\
\hline Cut & Paring knife & $\begin{array}{l}\text { Lateral cut made across the central body of the sweetpotato, approximately } 10 \mathrm{~mm} \text { deep } \\
\text { and } 30 \mathrm{~cm} \text { long }\end{array}$ \\
\hline $\begin{array}{l}\text { Macerating } \\
\text { bruise }\end{array}$ & $\begin{array}{l}589 \text {-g metal rod dropped through a } 0.75 \text {-inch } \\
\text { PVC pipe (to assist aim) }\end{array}$ & $\begin{array}{l}\text { 3- to } 5 \text {-mm deep, } 10 \text {-mm-diameter hole in the center of crushed tissue; placed on the } \\
\text { central body of the sweetpotato }\end{array}$ \\
\hline Abrasion & Kitchen zester/grater & $\begin{array}{l}\text { 1- to } 2 \text {-mm depth, approximately } 10 \mathrm{~mm} \text { wide and } 10 \mathrm{~mm} \text { long in accordance with } \\
\text { sweetpotato shape; placed on the central body of the sweetpotato }\end{array}$ \\
\hline Break & By hand & $\begin{array}{l}\text { Root tip broken off at the proximal end; exposed lateral cross-section, } 3-6 \mathrm{~cm} \text { in diameter } \\
\text { depending on the sweetpotato shape }\end{array}$ \\
\hline
\end{tabular}

\footnotetext{
${ }^{\mathrm{z}}$ The tools used and a description of injury produced for each wound type are included. Images of each wound, as observed on the experimental sweetpotatoes,
} can be seen in Figure 2. 
suspensions for treated roots or 5\% Tween for control roots were pipetted directly into the wound. Roots were then placed into sterile containers with the wound facing up.

The five temperatures tested were achieved by incubating the individual containers holding the sweetpotatoes in a growth chamber that had been set to one of the specified temperatures. Protocols used for achieving different RH levels were adapted from Scruggs and Quesada-Ocampo (2016b), in which RH was manipulated by adding 0,10 , or $15 \mathrm{ml}$ of SDW to each sterile container. Humidity levels were then maintained within each container, as container lids prevented air flow between the internal and external container environments. By using the individual, closed containers to control $\mathrm{RH}$, all treatment combinations of inoculum and humidity set at the same temperature were tested together in one incubator, reducing variability and the number of incubators required for this experiment. Watchdog model B102 data loggers (Spectrum Technologies, Plainfield, IL) were attached to the interior wall of one randomly selected plastic container per each inoculum $\times$ humidity $\times$ temperature combination to monitor temperature and $\mathrm{RH}$ for the duration of the experiment. Experimental RH values determined from data logger information can be found in Table 1 .

Lesion and sporulation area diameters on roots were evaluated at $4,7,11,14,18$, and 21 days postinoculation (dpi). Lesions were defined as circular, darkly discolored, and often sunken areas surrounding the puncture wound (Supplementary Fig. S1). Lesion diameters were measured by averaging the length of the longest diameter and the diameter of its perpendicular. Sporulation area was defined as the surface mycelial growth that always preceded the formation of the orange-tan ascospore masses and was visibly distinct from the lesion. The same method used for measuring lesion diameter was repeated for sporulation area diameters, but measured the mycelial growth instead. Area under the disease progress curve (AUDPC) values were calculated for lesion diameters $\left(\mathrm{AUC}_{\mathrm{D}}\right)$ and sporulation area diameters $\left(\mathrm{AUC}_{\mathrm{S}}\right)$ using the trapezoidal method in the Agricola package in $\mathrm{R}$ software (de Mendiburu 2017). The equation for AUDPC is as follows:
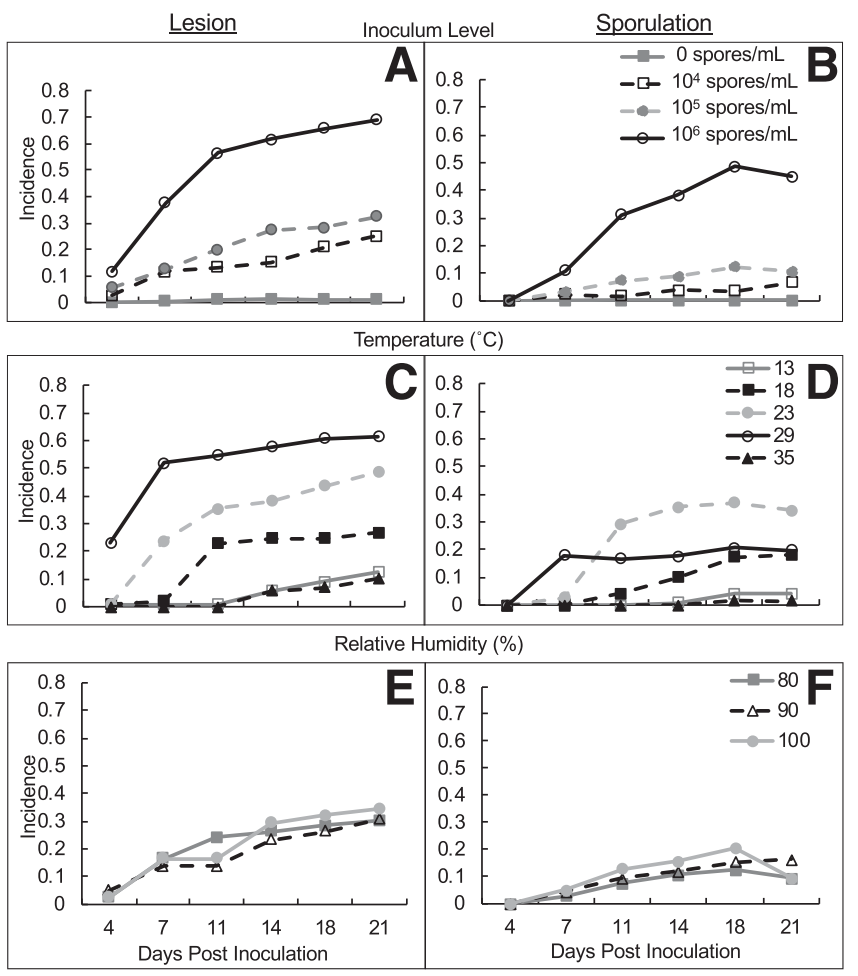

Fig. 1. Incidence ratings for lesion (A, C, E) and sporulation (B, D, F) incidence of sweetpotato black rot, caused by Ceratocystis fimbriata, at each time point measured under different environmental conditions. Ratings are categorized by inoculum level $(\mathbf{A}, \mathbf{B})$, temperature (C, D), and relative humidity $(\mathbf{E}, \mathbf{F})$.

$$
A U D P C=\sum_{i=1}^{N i-1} \frac{\left(\text { Diameter }_{i}+\text { Diameter }_{i+1}\right)}{2}\left(t_{i+1}-t_{i}\right)
$$

where diameter is the lesion or sporulation area diameter measured and $t$ is the dpi corresponding to the diameter measurement. The experiment was arranged in a factorial design with humidity and inoculum density treated as factors within temperature. Individual containers were treated as the experimental unit, and the roots within each container were treated as subsamples. Subsamples were averaged together during the statistical analysis. Generalized linear mixed model analyses were conducted on $\mathrm{AUC}_{\mathrm{D}}$ and $\mathrm{AUC}_{\mathrm{S}}$ data sets using the GLIMMIX procedure in SAS (version 9.4; SAS Institute Inc., Cary, NC). For both AUC response variables, the fixed effects were temperature, $\mathrm{RH}$, inoculum density, and all possible interactions of those terms. The random effects of the model were experimental repeat, experimental unit replicate (individual containers), and subsample (sweetpotatoes within each container) to account for the correct number of degrees of freedom. When interactions were present, the SLICE and SLICEBY statements were used to analyze simple effects. Means for effects found to be significant (alpha $=0.05, F \geq 4$ ) were separated with a Tukey-Kramer correction to determine differences among treatments.

Effect of wound type on disease development. The effect of wound type on pathogen growth was assessed for five wound types and a nonwounded control. The wounds tested were puncture, cut, macerating bruise, abrasion, and end breaks. All injuries to the experimental sweetpotatoes were inflicted on the central body of the root, with the exception of the end break, which was done at the proximal end of the root. Only one wound, or circled nonwounded area, was inflicted per root. A detailed description of all wound types and wounding tools used can be found in Table 2 .

A total of 12 roots were prepared for each wound type. Prior to wounding, roots were surfaced sterilized following the procedures mentioned above. Metal tools used for wounding were wiped clean and sterilized with $80 \%$ ethanol between each wounding event. After wounding, six roots of each wound type were placed into $40 \times 50 \times$ 18 -cm bins filled with either 6 liters of a $5 \times 10^{3}$ spores $/ \mathrm{ml}$ spore suspension or 6 liters of SDW to serve as a noninoculated control. Roots were left to soak in these containers for $20 \mathrm{~min}$. After inoculation, roots with the same wound and inoculum treatment were placed as pairs into the same clear, sterile containers as described previously, along with three paper towels and $15 \mathrm{ml}$ of sterile water to maintain approximately $100 \%$ RH within each container. The paired sweetpotatoes were evaluated as subsamples, which were averaged together during the statistical analyses, and the containers were evaluated as the experimental unit. The containers were then stored in a single growth chamber set to $23^{\circ} \mathrm{C}$ for a 21 -day period, and roots were rated

Table 3. Significance levels ( $F$ and $P$ values) from generalized linear mixed model analysis for the effects of temperature, humidity, and inoculum density on disease development of sweetpotato black rot as caused by Ceratocystis fimbriata

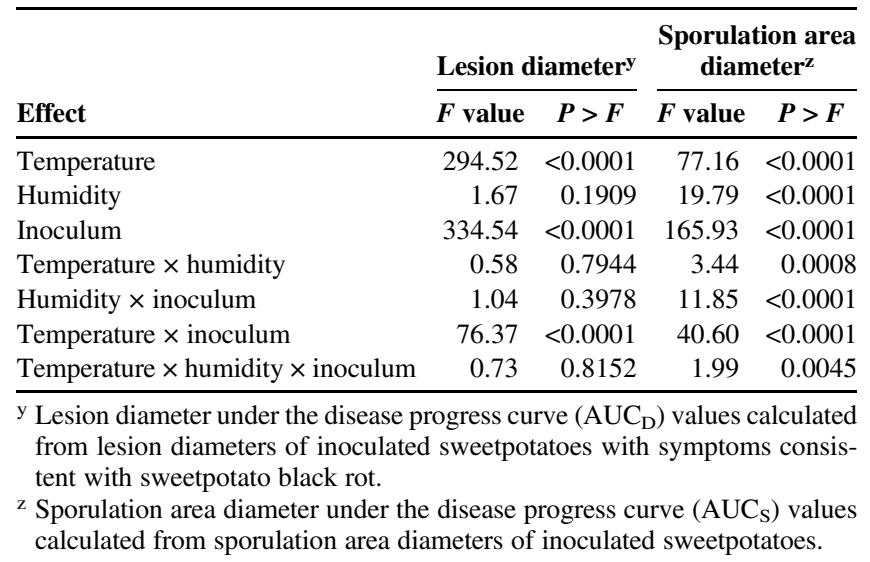


at $4,7,11,14,18$, and 21 days for disease incidence. The entire experiment was performed twice.

Sterile containers were arranged in the incubator following a complete randomized design, and incidence ratings for lesion and sporulation were taken as an indicator value of either 0 for no incidence or 1 for incidence observed. Generalized linear mixed model analyses with repeated measures were used to assess the wound lesion and sporulation incidence data sets using the GLIMMIX procedure in SAS. For both incidence response variables, the repeated measure was dpi with experimental repeat by wound as the subject with a compound symmetry covariance structure. The random effects of the model were experimental repeat, experimental unit replicate, and subsample to account for the correct number of degrees of freedom. The fixed effects were wound type, dpi, and the interaction between the two. The SLICE and SLICEBY statements were used to analyze simple effects of the interaction. Means for effects found to be significant (alpha $=0.05$ ) were separated with a TukeyKramer correction to determine differences among treatments.

\section{Results}

Effect of environmental conditions on disease development. After inoculation, infected roots developed dark, discolored, circular lesions consistent with sweetpotato black rot and exhibited sporulation at the inoculation point. When each environmental factor was considered separately, symptoms of disease were first observed at 4 dpi in roots exposed to inoculum concentrations of $10^{5}$ and $10^{6}$ spores $/ \mathrm{ml}$ (Fig. 1A), roots exposed to temperatures of $29^{\circ} \mathrm{C}$ (Fig. 1C), and roots exposed to all RHs tested (Fig. 1E). Signs of sporulation were first observed at 7 dpi in roots exposed to inoculum concentrations of $10^{5}$ and $10^{6}$ spores/ml (Fig. 1B) and exposed to all RHs tested (Fig. 1F). Roots kept at $29^{\circ} \mathrm{C}$ and a few roots at $23^{\circ} \mathrm{C}$ began sporulation at $7 \mathrm{dpi}$, but the majority of sporulation, for all temperatures other than 29 and $23^{\circ} \mathrm{C}$, did not begin until 11 dpi (Fig. 1D).

The effects of temperature, $\mathrm{RH}$, inoculum density, and all interactions between them on $\mathrm{AUC}_{\mathrm{D}}$ and $\mathrm{AUC}_{\mathrm{S}}$ were assessed, and all statistically significant interactions were screened for practical significance by instituting a $F$ value cutoff of 4 , owing to the large error degrees of freedom for most $F$ tests. Analysis indicated that temperature, inoculum density, and a temperature $\times$ inoculum interaction had a significant impact on both lesion and sporulation area $(P<$ 0.0001 ; Table 3 ). In addition, humidity and the humidity $\times$ inoculum interaction were also found to have a significant effect on $\mathrm{AUC}_{\mathrm{S}}$ only. Statistically, the temperature $\times$ humidity interaction and the three-way interaction between all main effects had a significant effect on $\mathrm{AUC}_{\mathrm{S}}$ at the $\alpha=0.05$ level, but these interactions were not practically significant because of their low $F$ values of 3.44 and 1.99 , respectively (Table 3 ). As a result of the presence of statistical interactions, only the simple effects within those interactions are described below.
Interactive effects of temperature and inoculum density. Lesions and sporulation structures developed within a temperature range of 18 to $29^{\circ} \mathrm{C}$ (Table 4). Signs and symptoms of disease were also observed at 13 and $35^{\circ} \mathrm{C}$, but the $\mathrm{AUC}_{\mathrm{D}}$ and $\mathrm{AUC}_{\mathrm{S}}$ values for all inoculum treatments within those temperatures were not significantly different from the nontreated control (Table 4). At temperatures where $\mathrm{AUC}_{\mathrm{D}}$ and $\mathrm{AUC}_{\mathrm{S}}$ values were statistically different from the noninoculated controls, lesion and sporulation areas were found to increase with inoculum density as a general trend. At $18^{\circ} \mathrm{C}, \mathrm{AUC}_{\mathrm{D}}$ and $\mathrm{AUC}_{\mathrm{S}}$ values at any inoculum concentration were consistently lower than AUC values calculated at 23 and $29^{\circ} \mathrm{C}$, and only the AUC values for the $10^{6}$ spores $/ \mathrm{ml}$ treatment were significantly greater than the noninoculated controls at that temperature. At $23^{\circ} \mathrm{C}, \mathrm{AUC}_{\mathrm{D}}$ and $\mathrm{AUC}_{\mathrm{S}}$ values for roots inoculated with $10^{5}$ and $10^{6}$ spores $/ \mathrm{ml}$ were significantly different from the noninoculated control and from each other. In addition, the largest sporulation area diameter observed across all treatment combinations, corresponding to an $\mathrm{AUC}_{\mathrm{S}}$ value of 45.95 , was observed at the $10^{6}$ spores $/ \mathrm{ml}$ by $23^{\circ} \mathrm{C}$ treatment (Table 4).

At $29^{\circ} \mathrm{C}, \mathrm{AUC}_{\mathrm{D}}$ and $\mathrm{AUC}_{\mathrm{S}}$ no longer maintained identical separations when assessed by inoculum density. Instead, $\mathrm{AUC}_{\mathrm{D}}$ values at all inoculum densities tested were significantly different from the nontreated control and from one another, whereas only the $10^{5}$ and $10^{6}$ spores $/ \mathrm{ml}$ treatments were significantly different than the nontreated control for $\mathrm{AUC}_{\mathrm{S}}$ (Table 4). Furthermore, the largest lesion diameter observed across all treatment combinations, corresponding to an $\mathrm{AUC}_{\mathrm{D}}$ value of 186.37 , was observed at the $10^{6}$ spores $/ \mathrm{ml}$ by $29^{\circ} \mathrm{C}$ treatment (Table 4 ).

Interactive effects of humidity and inoculum density on sporulation area. Of all main effects tested, humidity had the least significant effect on $\mathrm{AUC}_{\mathrm{S}}$, as indicated by a $F$ value of $19.76 \mathrm{com}-$ pared with 77.16 and 165.93 for temperature and inoculum density, respectively (Table 3 ). When considering the interactive effect of humidity and inoculum density, $\mathrm{AUC}_{\mathrm{S}}$ values for all RHs tested did not

Table 5. Interactive effect of relative humidity and inoculum density on sporulation area diameter of Ceratocystis fimbriata in sweetpotato roots under the disease progress curve $\left(\mathrm{AUC}_{\mathrm{S}}\right)$

\begin{tabular}{|c|c|c|c|c|}
\hline \multirow[b]{2}{*}{ RH } & \multicolumn{4}{|c|}{ Inoculum density (spores/ml) $)^{y}$} \\
\hline & 0 & $5 \times 10^{4}$ & $5 \times 10^{5}$ & $5 \times 10^{6}$ \\
\hline 85.53 & $0 a^{z}$ & $0.28 \mathrm{a}$ & $2.7 \mathrm{a}$ & $10.26 \mathrm{a}$ \\
\hline 94.09 & $0 \mathrm{a}$ & $1.07 \mathrm{a}$ & $3.01 \mathrm{a}$ & $15.67 \mathrm{~b}$ \\
\hline 97.01 & $0 \mathrm{a}$ & $1.45 \mathrm{a}$ & $4.75 \mathrm{a}$ & $26.09 \mathrm{c}$ \\
\hline$P$ value & 1 & 0.7476 & 0.3377 & $<0.0001$ \\
\hline
\end{tabular}

${ }^{y} \mathrm{AUC}_{\mathrm{S}}$ estimates for each inoculum density $\times$ relative humidity combination.

$\mathrm{z}$ Means within a column followed by the same letter are not significantly different $(P \leq 0.05)$.

Table 4. Interactive effect of temperature and inoculum density on lesion diameter $\left(\mathrm{AUC}_{\mathrm{D}}\right)$ and sporulation area diameter under the disease progress curve $\left(\mathrm{AUC}_{\mathrm{S}}\right)$ values for black rot of sweetpotato as caused by Ceratocystis fimbriata

\begin{tabular}{|c|c|c|c|c|c|}
\hline \multirow[b]{2}{*}{ Inoculum density (spores/ml) } & \multicolumn{5}{|c|}{ Temperature $\left({ }^{\circ} \mathrm{C}\right)^{\mathrm{y}}$} \\
\hline & 13 & 18 & 23 & 29 & 35 \\
\hline \multicolumn{6}{|l|}{$\overline{\mathrm{AUC}_{\mathrm{D}}}$} \\
\hline 0 & $0 \mathrm{a}^{\mathrm{z}}$ & $0 \mathrm{a}$ & $0 \mathrm{a}$ & $0 \mathrm{a}$ & $0 \mathrm{a}$ \\
\hline $5 \times 10^{4}$ & $1 \mathrm{a}$ & $4.01 \mathrm{a}$ & $7.76 \mathrm{a}$ & $68.52 \mathrm{~b}$ & $5.09 \mathrm{a}$ \\
\hline $5 \times 10^{5}$ & $0 \mathrm{a}$ & $0.72 \mathrm{a}$ & $35.77 \mathrm{~b}$ & $100.27 \mathrm{c}$ & $4.86 \mathrm{a}$ \\
\hline $5 \times 10^{6}$ & $8.59 \mathrm{a}$ & $56.73 \mathrm{~b}$ & $155.71 \mathrm{c}$ & $186.37 \mathrm{~d}$ & $2.89 \mathrm{a}$ \\
\hline$P$ value & 0.4032 & $<0.0001$ & $<0.0001$ & $<0.0001$ & 0.8347 \\
\hline \multicolumn{6}{|l|}{$\mathrm{AUC}_{\mathrm{S}}$} \\
\hline 0 & $0 \mathrm{a}^{\mathrm{y}}$ & $0 \mathrm{a}$ & $0 \mathrm{a}$ & $0 \mathrm{a}$ & $0 \mathrm{a}$ \\
\hline $5 \times 10^{4}$ & $0 \mathrm{a}$ & $0.21 \mathrm{a}$ & $0.92 \mathrm{a}$ & $3.21 \mathrm{ab}$ & $0.33 \mathrm{a}$ \\
\hline $5 \times 10^{5}$ & $0 \mathrm{a}$ & $0.08 \mathrm{a}$ & $12.38 \mathrm{~b}$ & $4.97 \mathrm{~b}$ & $0 \mathrm{a}$ \\
\hline $5 \times 10^{6}$ & $1.53 \mathrm{a}$ & $17.44 \mathrm{~b}$ & $45.95 \mathrm{c}$ & $21.37 \mathrm{c}$ & $0.42 \mathrm{a}$ \\
\hline$P$ value & 0.4032 & $<0.0001$ & $<0.0001$ & $<0.0001$ & 0.8347 \\
\hline
\end{tabular}

${ }^{\mathrm{y}} \mathrm{AUC}_{\mathrm{D}}$ (top) and $\mathrm{AUC}_{\mathrm{S}}$ (bottom) estimates for each temperature $\times$ inoculum density combination.

${ }^{\mathrm{z}}$ Means within a column followed by the same letter are not significantly different $(P \leq 0.05)$. 
significantly differ from one another within the $10^{4}$ and $10^{5}$ spores $/ \mathrm{ml}$ treatment groups (Table 5). However, within the $10^{6} \mathrm{spore} / \mathrm{ml}$ treatment group, $\mathrm{AUC}_{\mathrm{S}}$ values reported for each $\mathrm{RH}$ were statistically different from one another, and $\mathrm{AUC}_{\mathrm{S}}$ increased as humidity increased (Table 5).

Effect of wound type on disease development. Wounding of any type increased disease incidence by the end of the 21-day period (Figs. 2 and 3A; Table 6). All wound types except puncture wounds were also found to significantly increase sporulation incidence at the end of the 21-day period (Fig. 3B; Table 6). Overall, end breaks were found to be the most susceptible to disease, as all roots treated with inoculum developed lesions by the first time point ( $4 \mathrm{dpi})$. This trend was also observed for sporulation, as significantly more inoculated roots with end breaks had sporulation by 7 dpi compared with all other wound types and the nonwounded control (Fig. 3B).

The remaining four wound types (cut, bruise, puncture, and abrasion) appeared statistically similar in lesion development for the full experiment. Inoculated roots with these wounds did not show full separation from the nonwounded controls until 7 dpi but maintained the separation for the remainder of the experiment (Fig. 3A). Sporulation incidence followed a different trend with more gradual changes over time (Fig. 3B). By $11 \mathrm{dpi}$, roots wounded with macerating bruises showed significantly greater sporulation incidence than the control but did not further increase in sporulation incidence for the remainder of the experiment (Table 6). Abrasion and cut wounds had significantly greater sporulation incidence than the control by 14 and 18 dpi, respectively, but puncture wounds failed to separate from the nonwounded controls by the end of the experiment (Table 6).

\section{Discussion}

Because of the nature of sweetpotato production, sweetpotatoes are cured and stored directly after harvest (Fig. 4). As a result, any

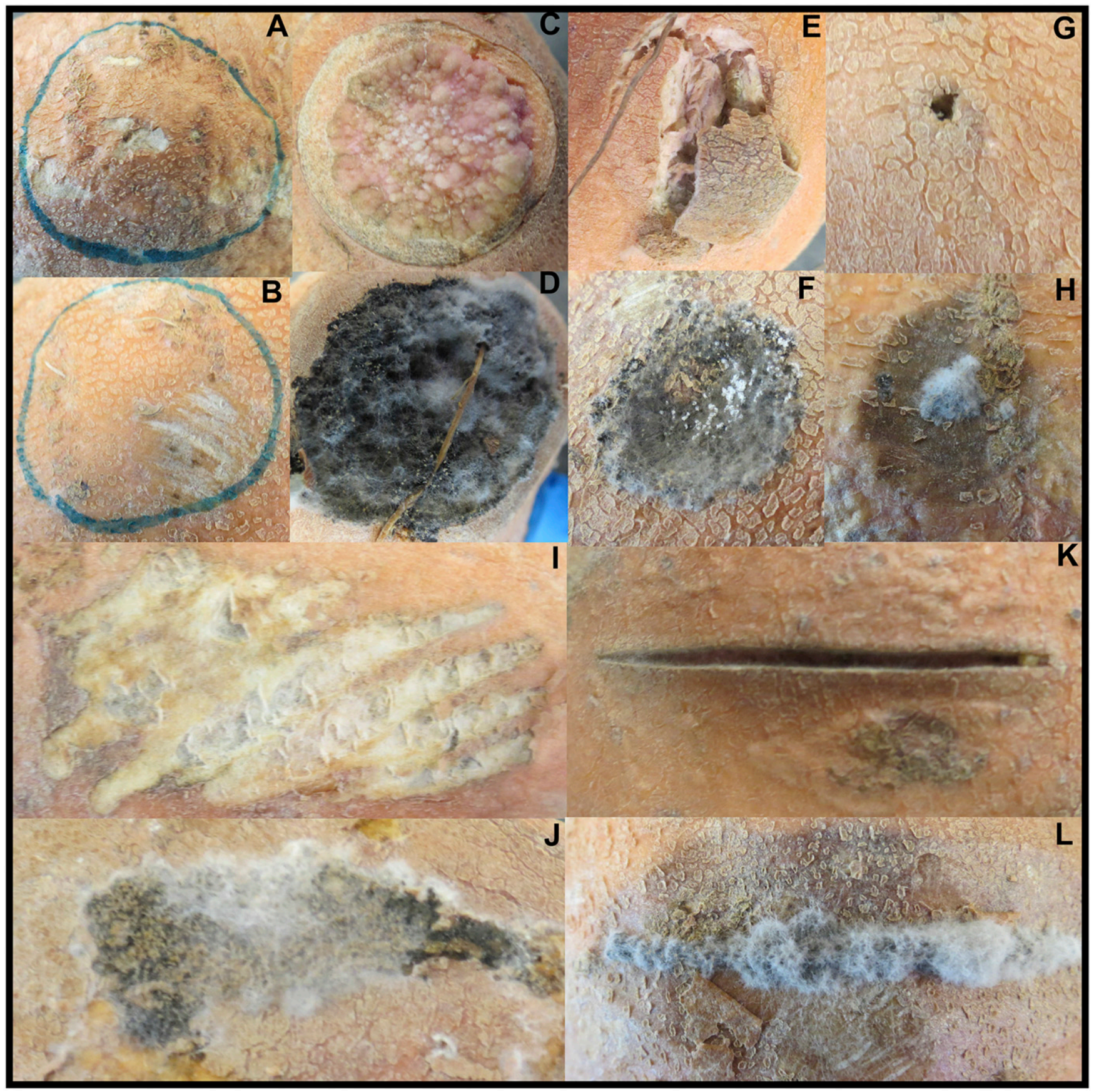

Fig. 2. Pairwise comparisons of noninoculated and Ceratocystis fimbriata inoculated sweetpotato roots for each wounding type, respectively. A and B, Nonwounded controls. C and D, End breaks. E and F, Macerating bruise. $\mathbf{G}$ and $\mathbf{H}$, Puncture. I and J, Abrasions. $\mathrm{K}$ and L, Cut. 
soil, microbes, and subsequently postharvest pathogens that were present from the field will remain with the sweetpotatoes throughout curing and storage. Removal of the pathogen through washing of sweetpotato roots prior to storage could be used to reduce inoculum load during the storage period, but would require a change in the sweetpotato production cycle and may result in other disease and horticultural issues due to added moisture. Until further studies are done to assess the effectiveness of washing roots prior to storage, the next logical option for disease prevention is to prevent a favorable environment for disease development. The two different experiments in this study were designed to identify conditions favorable for disease

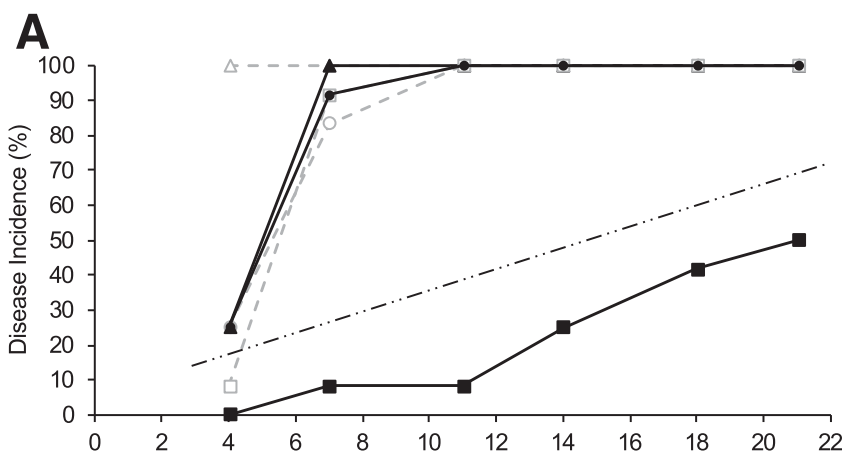

B

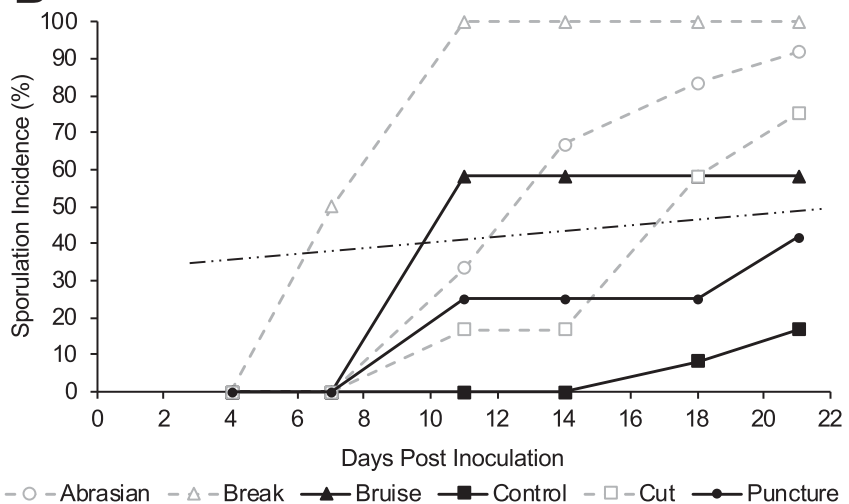

Fig. 3. Disease (A) and sporulation (B) incidence of sweetpotato black rot, caused by Ceratocystis fimbriata, as effected by wound over time. The dotted line represents data points that were significantly different from the non-wounded control. Values are averaged between both replications. development by investigating environmental factors and wounding of sweetpotato roots.

Investigation into environmental conditions revealed that inoculum density, temperature, and the interaction between the two had the greatest effect on disease progression. Lesions became largest in size when roots were kept at $29^{\circ} \mathrm{C}$ and inoculated with the highest spore concentration of $5 \times 10^{6}$ spores $/ \mathrm{ml}$. Although occurring in the same temperature range, sporulation had a different optimal temperature than lesion development, with the highest amount of sporulation occurring in roots kept at $23^{\circ} \mathrm{C}$, when also exposed to high spore concentrations of $5 \times 10^{6}$ spores $/ \mathrm{ml}$ and an RH of $97 \%$. Temperature and inoculum density are common influencers of disease progression among postharvest pathogens, as seen in studies with Fusarium and Rhizopus spp. in sweetpotatoes (Scruggs and QuesadaOcampo 2016b). The importance of these factors should not be underestimated, as demonstrated by the pome fruit postharvest pathogen Penicillium expansum, which was able to infect nonhost citrus fruits when exposed to high inoculum levels at optimal temperatures for the pathogen (Vilanova et al. 2012).

Because the experimental design inherently linked humidity to temperature, only a limited range of $\mathrm{RH}$ (85.53, 94.09, and $97.01 \%$ ) was achieved in this experiment, differing from the desired theoretical values by 3 to $6 \%$. This range still contained the current industry-recommended sweetpotato storing RH of $85 \%$ (Edmunds et al. 2008) and was thus retained for data analysis. Although RH did not have a significant effect on lesion development, $\mathrm{RH}$ and the interaction between humidity and inoculum density had a significant effect on sporulation areas in experimental roots but only in roots treated with $10^{6}$ spores $/ \mathrm{ml}$. Under this inoculum treatment, roots grouped by RH completely separated from one another, with sporulation area diameters significantly increasing with RH. However, further studies would be necessary to investigate the role of lower RH and the effects it may have on disease development.

This information about environmental conditions can be used to improve disease management strategies for sweetpotato black rot. Of all environmental factors, temperature of storage facilities would be the easiest to control. Disease reduction at $13^{\circ} \mathrm{C}$ is encouraging, as this is the current recommended temperature for long-term root storage (Edmunds et al. 2008; Smith et al. 2009). However, the current recommended curing temperature is $29^{\circ} \mathrm{C}$ (Edmunds et al. 2008), which was found to be the optimal temperature for $C$. fimbriata lesion development and allowed for significant amounts of sporulation on roots exposed to high levels of inoculum and humidity. Additionally, based on storage room size, condition of the storage facility, and even outside climate, recommended temperatures are not always maintained in storage rooms. A small increase in temperature to $18^{\circ} \mathrm{C}$ during sweetpotato storage could allow for lesion and spore

Table 6. Interactive effect of time and wound type on black rot disease and sporulation incidence in sweetpotato roots over repeated measures

\begin{tabular}{|c|c|c|c|c|c|c|}
\hline \multirow[b]{2}{*}{ Days postinoculation } & \multicolumn{6}{|c|}{ Lesion incidence $(\%)$} \\
\hline & Control & Abrasion & Break & Bruise & Cut & Puncture \\
\hline 4 & $0.00 \mathrm{a}^{\mathrm{z}}$ & $25.00 \mathrm{a}$ & $100.00 \mathrm{a}$ & $25.00 \mathrm{a}$ & $8.33 \mathrm{a}$ & $25.00 \mathrm{a}$ \\
\hline 7 & $8.33 \mathrm{ab}$ & $83.33 \mathrm{~b}$ & $100.00 \mathrm{a}$ & $100.00 \mathrm{a}$ & $91.67 \mathrm{~b}$ & $91.67 \mathrm{~b}$ \\
\hline 11 & $8.33 \mathrm{ab}$ & $100.00 \mathrm{~b}$ & $100.00 \mathrm{a}$ & $100.00 \mathrm{a}$ & $100.00 \mathrm{~b}$ & $100.00 \mathrm{~b}$ \\
\hline 14 & $25.00 \mathrm{bc}$ & $100.00 \mathrm{~b}$ & $100.00 \mathrm{a}$ & $100.00 \mathrm{a}$ & $100.00 \mathrm{~b}$ & $100.00 \mathrm{~b}$ \\
\hline 18 & $41.67 \mathrm{~cd}$ & $100.00 \mathrm{~b}$ & $100.00 \mathrm{a}$ & $100.00 \mathrm{a}$ & $100.00 \mathrm{~b}$ & $100.00 \mathrm{~b}$ \\
\hline 21 & $50.00 \mathrm{~d}$ & $100.00 \mathrm{~b}$ & $100.00 \mathrm{a}$ & $100.00 \mathrm{a}$ & $100.00 \mathrm{~b}$ & $100.00 \mathrm{~b}$ \\
\hline \multirow[t]{2}{*}{$P$ value } & $<0.0001$ & $<0.0001$ & 1 & $<0.0001$ & $<0.0001$ & $<0.0001$ \\
\hline & \multicolumn{6}{|c|}{ Sporulation incidence (\%) } \\
\hline 4 & $0.00 \mathrm{a}$ & $0.00 \mathrm{a}$ & $0.00 \mathrm{a}$ & $0.00 \mathrm{a}$ & $0.00 \mathrm{a}$ & $0.00 \mathrm{a}$ \\
\hline 7 & $0.00 \mathrm{a}$ & $0.00 \mathrm{a}$ & $50.00 \mathrm{~b}$ & $0.00 \mathrm{a}$ & $0.00 \mathrm{a}$ & $0.00 \mathrm{a}$ \\
\hline 11 & $0.00 \mathrm{a}$ & $33.33 \mathrm{~b}$ & $100.00 \mathrm{c}$ & $58.33 \mathrm{~b}$ & $16.67 \mathrm{a}$ & $25.00 \mathrm{ab}$ \\
\hline 14 & $0.00 \mathrm{a}$ & $66.67 \mathrm{c}$ & $100.00 \mathrm{c}$ & $58.33 \mathrm{~b}$ & $16.67 \mathrm{a}$ & $25.00 \mathrm{ab}$ \\
\hline 18 & $8.33 \mathrm{a}$ & $83.33 \mathrm{c}$ & $100.00 \mathrm{c}$ & $58.33 \mathrm{~b}$ & $58.33 \mathrm{~b}$ & $25.00 \mathrm{ab}$ \\
\hline 21 & $16.67 \mathrm{a}$ & $91.67 \mathrm{c}$ & $100.00 \mathrm{c}$ & $58.33 \mathrm{~b}$ & $75.00 \mathrm{~b}$ & $41.67 \mathrm{~b}$ \\
\hline$P$ value & 0.7514 & $<0.0001$ & $<0.0001$ & $<0.0001$ & $<0.0001$ & 0.0127 \\
\hline
\end{tabular}

${ }^{\mathrm{z}}$ Means within a column followed by the same letter are not significantly different $(P \leq 0.05)$. 
development. In addition, during curing, lower temperatures may result in decreased lesion size but increased sporulation, whereas higher temperatures may reduce overall disease development but would introduce heat damage to the sweetpotato roots.

The amount of inoculum generated within the sporulation area was not quantified in this study because it would have required destructive sampling. However, this study indicates that formation of secondary inoculum could be managed through $\mathrm{RH}$, which is encouraging because reducing primary inoculum would be difficult and require cultural control practices prior to sweetpotato harvest. The mechanism in which RH influences sporulation of $C$. fimbriata is unclear, but such an observation is not isolated. Several types of fungi require high humidity for sporulation in different pathosystems, either to serve as an environmental cue for spore production or as a necessary requirement for spore germination (Rotem et al. 1978). Fusarium and Rhizopus sp., other postharvest pathogens of sweetpotato, were found to sporulate in infected roots earlier and more consistently when exposed to RH of $90 \%$ and higher or $100 \%$, respectively (Scruggs and Quesada-Ocampo 2016a, b). This is consistent with other pathogens in the Ceratocystis genus, as ascosporeproducing perithecia can be coaxed to form on infected plant tissue when placed in a moist chamber (Harrington 2013). Given that

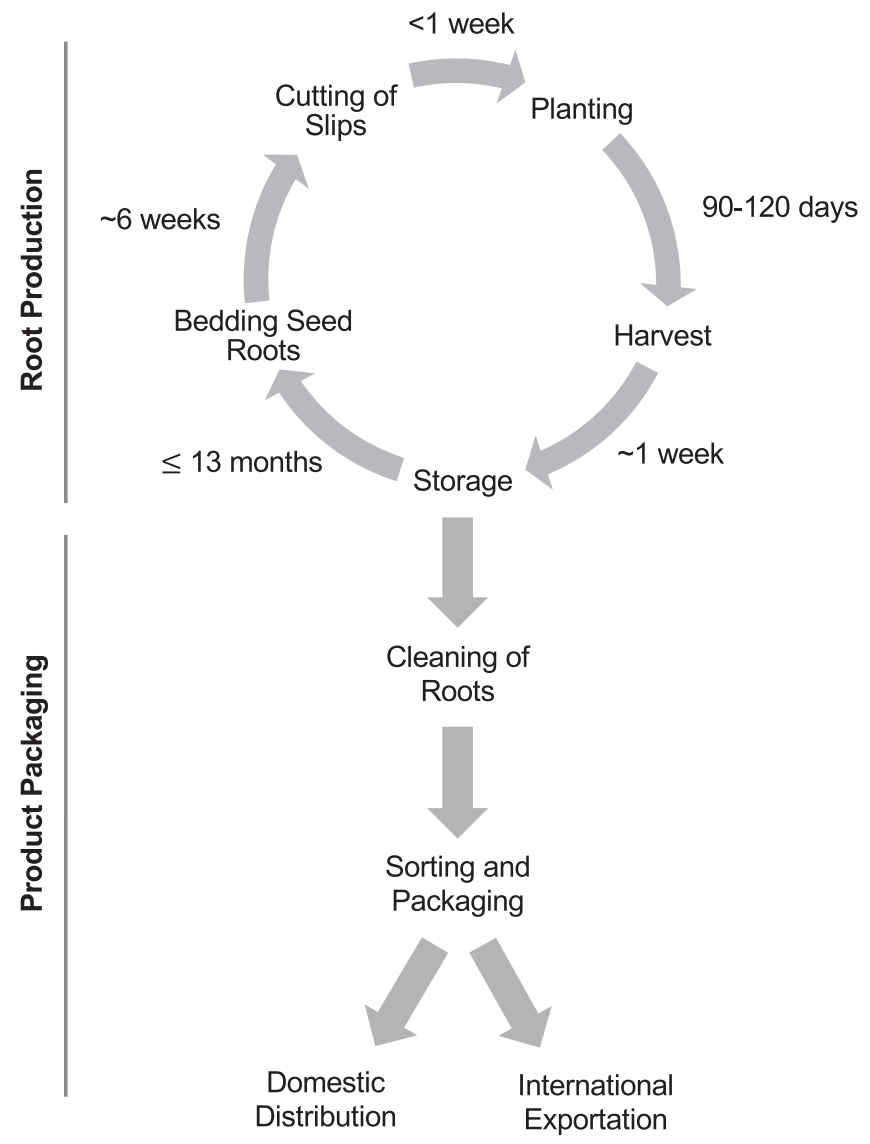

Fig. 4. Flow chart of sweetpotato production. Sweetpotato production starts with a yearly cyclic process to produce marketable roots. Seed roots left over from the prior harvest are bed into greenhouses or nursery fields for vine production. After about six weeks the vines are then cut one inch above the soil line to produce vegetative slips, which are transplanted into the field. Sweetpotato roots are harvested between 90 and 120 days after planting, depending on the variety, and harvested roots are taken to packing facilities to be cured and stored, while still bearing soil from the field. Cured roots are then stored up to 13 months and are removed from storage either for sale or to serve as seed roots for the following year. Only sweetpotatoes intended for sale are cleaned to remove soil using large dump tanks filled with water. After passing through the dump tank, roots are sent down an automated packing line where they are sprayed with sanitizers and approved fungicides, sorted based on size, and packaged for shipment. Roots are then shipped for domestic use or exported internationally, which may require a shipping period of up to 21 days. ascospore masses of $C$. fimbriata are in a wet, sticky extracellular matrix, the fungi may require high humidity to develop this matrix or to prevent desiccation before germination, but further investigation would be necessary for verification.

Wound prevention can also be used for disease management in sweetpotato, as many postharvest pathogens are opportunistic. Even so, wounding cannot be avoided entirely and this study determined that wounds, of any type, on the sweetpotato root significantly increased black rot incidence. Roots with end breaks had the most profound effect on disease incidence, as experimental roots had fully developed lesions within the first 7 days and exhibited as much sporulation at that point as the nonwounded inoculated roots would incur over the whole duration of the experiment. Of the remaining wound types, all were more susceptible to infection with $100 \%$ lesion incidence achieved by $11 \mathrm{dpi}$, and only puncture wounds were not found to have significantly greater sporulation than the control by the end of the experiment.

The level of infection observed in this portion of the study was surprising, given how low infection rates were for roots inoculated with $10^{4}$ spores $/ \mathrm{ml}$ and kept at $23^{\circ} \mathrm{C}$ in the environmental study. Even so, a high percentage of inoculated roots developed symptoms at this lower inoculum rate $\left(10^{3} \mathrm{spores} / \mathrm{ml}\right)$. The increased infection rate was most likely attributable to the change in inoculation method-from direct injection of a spore suspension into a puncture wound, to prolonged root submersion in a spore suspension. It is unlikely that prolonged submersion could have elicited a water stress response in the roots, such as that seen with geotrichum sour rot that develops in stored sweetpotatoes pulled from flooded fields (Edmunds et al. 2008; Holmes 2013), as the 20-min submersion done in this study is not long enough to cause root asphyxiation. Another, more likely possibility is that submersion of roots led to increased opening of the lenticels, providing access to pathogen entry. Although less research has been done in sweetpotato, studies with white potato tubers indicated that placing tubers in damp soil or wrapping them in wet paper towels led to increased infection with Streptomyces scabies (Adams and Lapwood 1978), Erwinia carotovora, and Phytophthora infestans (Adams 1975).

The size and texture of the different wound types may have also played a role in increasing infection rates, as most wounds were larger and produced a different surface texture than a singular puncture wound and could have allowed for more efficient spore attachment. Because the end-break wound created the largest injury and left an open, uneven surface for spores to attach, this could have been why end-break roots were so susceptible to infection. End breaks were also one of the wound types that exposed tissues below the cortex. Black rot infections are typically shallow and do not often pass this tissue layer (Clark and Moyer 2013), so these exposed inner tissues could have been more susceptible to infection. Finally, mechanisms that allow spores to either find or adhere more easily to roots when in suspension could also be a factor, but currently no work has been done to indicate that such mechanisms exist.

This study has helped fill some of the gaps within the black rot pathosystem by determining favorable environmental storage conditions and preferred wound types for $C$. fimbriata when infecting sweetpotato. Although certain environments cannot be avoided, growers should be mindful to prevent favorable conditions when possible. Wound prevention efforts should be continued at all sweetpotato production stages, and sweetpotatoes should be cured as quickly as possible after harvest to allow for wound healing before infection can occur. Storage rooms should be closely monitored to prevent temperature increases during the many months sweetpotatoes can be held before packaging. Such practices can help reduce the risk of black rot outbreaks, but further research is still necessary to answer many of the unknowns in this pathosystem and provide growers with an arsenal of tactics to use against $C$. fimbriata.

\section{Acknowledgments}

We thank all of the members of the Quesada laboratory for their valuable help. We also thank the numerous sweetpotato farms in North Carolina that allowed us to sample diseased roots and that donated roots for use in this study. 


\section{Literature Cited}

Adams, M. J. 1975. Potato tuber lenticels: Susceptibility to infection by Erwinia carotovora var. atroseptica and Phytophthora infestans. Ann. Appl. Biol. 79: 275-282.

Adams, M. J., and Lapwood, D. H. 1978. Studies on the lenticel development, surface microflora and infection by common scab (Streptomyces scabies) of potato tubers growing in wet and dry soils. Ann. Appl. Biol. 90:335-343.

Baker, C. J., Harrington, T. C., Krauss, U., and Alfenas, A. C. 2003. Genetic variability and host specialization in the Latin American clade of Ceratocystis fimbriata. Phytopathology 93:1274-1284.

Baker Engelbrecht, C. J., and Harrington, T. C. 2005. Intersterility, morphology and taxonomy of Ceratocystis fimbriata on sweet potato, cacao and sycamore. Mycologia 97:57-69.

Bickers, C. 2015. Sweet potatoes: Juice, pet food products could increase market demand. Southeast Farm Press. https://www.farmprogress.com/vegetables/ sweet-potatoes-juice-pet-food-products-could-increase-market-demand

Clark, C. A., and Moyer, J. W. 2013. Black rot. Pages 29-33 in: Compendium of Sweetpotato Diseases, Pests, and Disorders. C. A. Clark, D. Ferrin, T. Smith, and G. Holmes, eds. American Phytopathological Society, St. Paul, MN.

de Mendiburu, F. 2017. agricolae: Statistical Procedures for Agricultural Research. R package version 1.2-8. https://CRAN.R-project.org/package=agricolae

Edmunds, B., Boyette, M., Clark, C., Ferrin, D., Smith, T., and Holmes, G. 2008. Postharvest Handling of Sweetpotatoes. North Carolina State University. North Carolina Cooperative Extension Service, Zebulon.

Food and Agriculture Organization of the United Nations. 2014. FAOSTAT. http://www.fao.org/faostat/en/\#home

Halsted, B. D. 1890. Some fungous diseases of the sweet potato. N. J. Agric. Coll. Exp. Stn. Bull. 76:25-27.

Harrington, T. C. 2013. Ceratocystis diseases. Pages 230-251 in: Infectious Forest Diseases. Gonthier, P., and Nicolotti, G., eds. CAB International, London, UK.

Holmes, G. 2013. Geotrichum sour rot. Pages 42-44 in: Compendium of Sweetpotato Diseases, Pests, and Disorders. C. A. Clark, D. Ferrin, T. Smith, and G. Holmes, eds. American Phytopathological Society, St. Paul, MN.

Holmes, G. J., and Stange, R. 2002. Influence of wound type and storage duration on susceptibility of sweetpotatoes to Rhizopus soft rot. Plant Dis. 86:345-348.

Johnson, T., Wilson, N., Worosz, M. R., Fields, D., and Bond, J. K. 2015. Commodity highlight: Sweet potatoes. Pages 1-6 in: Economic Research Service: Situation and Outlook. U.S. Department of Agriculture Economic Research Service, Washington, DC

Kushman, L. J., and Cooley, J. S. 1946. Effect of heat on black rot and keeping quality of sweetpotatoes. J. Agric. Res. 78:183-190.
Lauritzen, J. I. 1926. Infection and temperature relations of black rot of sweetpotato in storage. J. Agric. Res. 33:663-676.

Lauritzen, J. I. 1935. Factors affecting infection and decay of sweetpotatoes by certain storage rot fungi. J. Agric. Res. 50:285-329.

Loebenstein, G. 2009. Origin, distribution, and economic importance. Pages 9-12 in: The Sweetpotato. G. Loebenstein and G. Thottappilly, eds. Springer, New York, NY.

Morris, L. L., and Mann, L. K. 1955. Wound healing, keeping quality, and compositional changes during curing and storage of sweet potatoes. Hilgardia 24:143-183.

North Carolina Department of Agriculture and Consumer Services. 2015. Marketing North Carolina Sweetpotatoes. Federal-State Market News Service, Raleigh, NC.

Quesada-Ocampo, L. M. 2014. Vegetable Pathology Fact Sheets: Black Rot of Sweetpotato. NC State Extension, Raleigh.

Rotem, J., Cohen, Y., and Bashi, E. 1978. Host and environmental influences on sporulation in vivo. Annu. Rev. Phytopathol. 16:83-101.

Scott, G. J. 1992. Sweet potatoes as animal feed in developing countries: Present patterns and future prospects. Page 95 in: Roots, Tubers, Plantains and Bananas in Animal Feeding. D. Machin and S. Nyvold, eds. Food and Agriculture Organization of the United Nations, Rome, Italy.

Scruggs, A. C., Basaiah, T., Adams, M. L., and Quesada-Ocampo, L. M. 2017. Genetic diversity, fungicide sensitivity, and host resistance to Ceratocystis fimbriata infecting sweetpotato in North Carolina. Plant Dis. 101:994-1001.

Scruggs, A. C., and Quesada-Ocampo, L. M. 2016a. Cultural, chemical, and alternative control strategies for Rhizopus soft rot of sweetpotato. Plant Dis. 100:1532-1540.

Scruggs, A. C., and Quesada-Ocampo, L. M. 2016b. Etiology and epidemiological conditions promoting Fusarium root rot in sweetpotato. Phytopathology 106: 909-919.

Smith, T. P., Stoddard, S., Shankle, M., and Schultheis, J. 2009. Sweetpotato production in the United States. Pages 287-325 in: The Sweetpotato. G. Loebenstein and G. Thottappilly, eds. Springer, New York, NY.

Vilanova, L., Vinas, I., Torres, R., Usuall, J., Jauset, A. M., and Teixido, N. 2012. Infection capacities in the orange-pathogen relationship: Compatible (Penicillium digitatum) and incompatible (Penicillium expansum) interactions. Food Microbiol. 29:56-66.

Wiemer, J. L., and Harter, L. L. 1921. Wound-cork formation in the sweet potato. J. Agric. Res. 21:637-647.

Woolfe, J. A. 1998. Sweet potato: An untapped food source. Press Syndicate of the University of Cambridge, New York, NY. 